\title{
Pedagogical Methods and Technology Used in Chemistry Secondary Education
}

\section{Kristen KB ${ }^{1}$, Malinda WG ${ }^{*}$, Monica $\mathrm{D}^{2}$ and Kendra $\mathrm{M}^{3}$}

${ }^{1}$ Department of Physics, Chemistry and Mathematics, College of Engineering, Technology and Physical Sciences, Alabama Agricultural and Mechanical University, Normal, Alabama, USA

${ }^{2}$ Department of Curriculum and Instruction, College of Education, University of Alabama at Huntsville, Huntsville, Alabama, USA

${ }^{3}$ Online Learning, Office of Information Technology, University of Alabama at Huntsville, Huntsville, Alabama, USAI

\begin{abstract}
The art of teaching is continuously evolving and advancing, making chemistry teachers re-evaluate their methods of instruction every year. The purpose of this review is to identify current pedagogical methods and technologies best used to teach chemistry in secondary schools. The science based pedagogies such as problem-based learning (PBL), process-oriented guided inquiry learning (POGIL), [1], and project-based learning (PjBL) aligned with the application of appropriate technology servers are the core foundation for teaching all $21^{\text {st }}$ century learners.
\end{abstract}

Keywords: Pedagogical methods; Chemistry; Secondary education

\section{Introduction}

Secondary chemistry teachers face a host of challenges as they are given the responsibility of deciding how they will deliver assigned curriculum. Much like a complex equation, teachers must factor in numerous variables that will change every semester or year depending on student loads, student needs, grade levels, maturity, development, resources, as well as environmental factors outside the school. These intricate variables play a crucial role in developing a solution to this complex equation. Once the educator has determined those unknown variables, a decision can be made as to which pedagogical and technological methods to apply. A central theme herein is the "Social Constructivist Learning Theory." The "Social Constructivist Learning Theory" implies that students learn better through active interactions with their peers rather than listening to lectures [2]. Social constructivist's reason that through peer interactions, students are able to process new information in a way that's understandable to them, therefore leading to higher order thinking [3]. Science-based pedagogies that support the "Social Constructivist Learning Theory" are problem-based learning $(\mathrm{PBL})$, process-oriented guided inquiry (POGIL), and project-based learning (PjBL) [4-7]. Educational technology is one of the greatest resources we have to help our students learn. While chemistry is a part of our everyday lives, students have found that chemistry can be difficult to understand [8]. If a student is found to be weak in one area, additional support should be given to help that student strengthen their weak area so that they too can have an opportunity to realize their full potential.

For teachers, finding time to provide additional support to help students overcome weak areas can be very difficult. Using technology as a way for students to build skills in weak subject areas will make difficult times of learning fun and enjoyable, but most importantly it will help students build the confidence they need to succeed. Technology is not only beneficial to struggling students; rather, it is beneficial to all students. By using technology, teachers can bring chemistry to life and students will be able to visualize abstract concepts and test new learned concepts in chemistry. For $21^{\text {st }}$ century learners, incorporating technology into the classroom is critical (Saba). Exposing students to technology while teaching chemistry will increase their knowledge and help them build skills that will make them competitive in the STEM workforce (Strengthen Science Education and the Scientific Workforce - American Chemical Society). Active learning is facilitated through students' activities and by promoting student engagement. Redish et al. [9] demonstrated in a study with their students, that achieving significant gains is possible, using active learning as opposed to didactic lectures enhances student learning continuously after missing fundamental concepts. Science pedagogies discussed in this paper facilitate active learning and student engagement, through an inquirybased problem approach. Pedagogical strategies reviewed in this article can be implemented independently of each other or in conjunction within an instructional setting. Problem-Based Learning is a science based pedagogy that was first implemented in medical schools during the seventies to help students retain large amounts of information through open-ended questions [10].

Students are broken into groups of 3-5 and presented with a real life, open-ended problems or questions given by their teacher. In order for students to achieve higher-order thinking, problems or questions should encompass several topics within the subject of chemistry. During the process of working through a problem, students identify problems, activate prior knowledge, and construct new knowledge in a comprehendible framework that is linked to prior knowledge learned [5,11]. Tarhan et al. [8] described in great detail their PBL success with a group of $9^{\text {th }}$ grade chemistry students and $11^{\text {th }}$ grade students. In groups, the $9^{\text {th }}$ grade students worked on solving a chemistry problem centered on London dispersion forces. The teacher circulated around the room and asked guided questions as the groups worked on the problem. During group discussion, one group reasoned polytetrafluoroethen's (Teflon) weak London dispersion forces made it difficult for food to stick to the pan. Other groups gave other real-life examples of London dispersion forces citing uses of graphite and oil. During the last 15 minutes of class, the teacher introduced new content that would be addressed in the next session. Chemistry students using PBL will develop $21^{\text {st }}$ century workforce skills such as problem-solving, critical-thinking, self-guided learning, communication and teamwork ("Problem-Based Learning | CRLT", 2016). Process-Oriented Guided Inquiry Learning (POGIL) is style of teaching that is designed to replace lectures in the

*Corresponding author: Malinda Wilson Gilmore, Department of Physics, Chemistry and Mathematics, College of Engineering, Technology and Physical Sciences, Alabama Agricultural and Mechanical University, Normal, Alabama, USA, Tel: 7138227879; E-mail: malinda.gilmore@gmail.com

Received June 21, 2017; Accepted June 27, 2017; Published July 03, 2017

Citation: Kristen KB, Malinda WG, Monica D, Kendra M (2017) Pedagogical Methods and Technology Used in Chemistry Secondary Education. Mod Chem appl 5: 223. doi: 10.4172/2329-6798.1000223

Copyright: (c) 2017 Kristen KB, et al. This is an open-access article distributed under the terms of the Creative Commons Attribution License, which permits unrestricted use, distribution, and reproduction in any medium, provided the original author and source are credited. 
classroom through a three-phase learning cycle. POGIL's three phase learning cycle: 1) exploration phase, 2) concept invention to formation phase, and 3) application phase, all mirror the brain's cognitive learning process for new information $[4,12]$.

During the exploration phase, students analyze models to collect as much information as possible, looking for patterns and relationships. In the concept phase, students conceptualize the observed patterns and relationship and the name of the concept learned is revealed. Application phase is the last phase of the learning cycle and it is during this time that students apply concepts learned to new situations $[1,13]$. Instructor's Guide to Process-Oriented Guided-Inquiry Learning breaks down the steps necessary to carry out a POGIL lesson. The teacher breaks the class into groups of four where each student will then have a job as a leader, recorder, presenter or, evaluator. Groups are then given data, models, and/or information to analyze that is aimed to guide students learning. During this time, students will answer guided questions that build off of the prior questions. Students will begin to probe and create questions of their own. Once the group has processed the given information provided during the exploration phase, the students will begin to formulate their own hypothesis based on the patterns observed in the exploration phase. It is during this time the new learned concept is given a formal name. Together the exploration phase and the concept invention phase allow students to have a good working knowledge of the concepts process before a formal name is given. During the application phase, students newly learned concepts are tested by applying the material learned to new situations. The application phase allows students to build confidence in what they have learned [13]. Project-Based Learning (PjBL) is a method of teaching that facilitates learning though student engaged projects centered on concepts to be learned.

During the process of working on a project; students are creating, questioning, and revising knowledge, while developing their skills in critical thinking, collaboration, communication, reasoning, synthesis, and $[14,15]$ describes a successful project based learning lesson with $10^{\text {th }}, 11^{\text {th }}$ and $12^{\text {th }}$ grade students that was carried out in three parts; 1 ) research an element and create a virtual poster 2) research the atomic structure of the element and demonstrate understanding to the teacher using an info graphic and 3) research common uses of the element and tied this ideas to the prior knowledge of the properties and structures of their elements then created a video animation to teach their class. More efficient curriculum instruction, students learning skills outside of the required content, and relevance to students life [16] are a major reason why teachers choose PjBL as a method of teaching. As we are now in the $21^{\text {st }}$ century, today's chemistry teachers are faced with two main objectives when preparing lessons; (1) students mastering chemistry concepts and (2) building $21^{\text {st }}$ century skills for STEM jobs. Chemistry teachers should focus on helping students build $21^{\text {st }}$ century skills, such as critical thinking, creativity, meta-cognition or self-regulation, collaboration, information and technological literacy [17] in an effort to make students more competitive in the workforce. Online blogging is an excellent way for chemistry teachers to teach chemistry concepts, build $21^{\text {st }}$ century skills and keep students excited and focused about learning chemistry. While blogging can be done though discussion boards, using sites, such as a wiki, allows students to actually conduct group projects in class or at home while being able to monitor progress in real-time [18].

Incorporating the use of student smart phones in the classroom has proven to be a useful instructional tool, especially for teachers who have limited technology resources. Web browsers, applications (apps), and $2 \mathrm{D}$ barcodes to create smart objects, can all serve as learning tools that facilitate independent learning [19]. Video tutorials and quizzes can serve as differential methods of instruction for chemistry teachers inside and outside of the classroom. For example, Khan Academy is a popular site for chemistry teachers and teachers of other various content areas as well. Instructional methods for which Khan Academy can be utilized include, blended learning, one-to-one classrooms, and online classes [20]. Khan Academy provides data for teachers to see where they need to help their students who are struggling [21]. Branded by older generations as the "gamer generation" [22], chemistry teachers are now using online games as a way to actively engage students in learning chemistry concepts of all levels.

A simple google search of chemistry video games will put students in a virtual world of molecules, molar masses, and complex equations. Virtual labs are one of the most effective ways for chemistry teachers to engage their students with active learning [23]. Virtual labs allow students to experience what it is like to experience a chemistry job in a stem field. This is an excellent way for students to realize their own potential by getting to think like they are working in a field. Students become actively engaged when they are able to see concepts being studied, applied to real life. Going from teacher-centered learning to student-centered learning can be a little nerve racking initially, for both the teacher and the student. Student-centered learning gives students the ability to actively learn and engage with their peers without depending on the teacher for answers. Of the three pedagogies discussed, problembased learning is one of the easiest teaching methods to implement due to minimal preparation time. It is important for problem-based questions to be relevant to real life so that students can identify with the problem, making it become personal. Case studies, vignettes, and open-ended task completion problems are the most common used [24]. Problem-Based Learning can be incorporated into the POGIL method during the application phase to test the new knowledge learned. The Process-Oriented Guided Inquiry Learning (POGIL) method is the newest and most challenging methodology to implement of the three methods. Teachers face a learning curve with initial implementation of POGIL; however, student success with this method in general chemistry classes is well documented [1].

When needed, teachers can provide mini lectures in between phases, as tier 2 instruction for students struggling. Project Based Learning $(\mathrm{PjBL})$ is a very popular and effective method to teach chemistry. Its growing popularity in recent years can be credited to the shift from teacher centered learning, to student centered learning. In the past, $\mathrm{PjBL}$, was an independent learning strategy, where students carried home and completed an assigned project, then returned back to school. Many students lack adequate support at home to complete these types of assignments, resulting in an overall negative impact on the students. Chemistry teachers, implementing project based learning inside of the classroom, can design projects to specifically meet the learning needs of students in their classroom [25]. An invaluable component that should be incorporated into each of these pedagogies is the use of $21^{\text {st }}$ century technology. For chemistry teachers who use lecture and textbooks as their primary instructional tool, incorporating technology into instruction is imperative to the success of struggling chemistry students. Pressure to strengthen writing skills, has fallen on all content teachers. Chemistry teachers must look for creative ways to build their students writing skills. Incorporating online blogging, discussion boards, or constructing wiki pages allows students to build online literacy skills, which is a critical asset in today's workforce. Smartphones are one of the simplest ways of implementing technology in the classroom, however, it should be noted that implementing smartphones into lessons, without adequate preparation by the teacher, 
can result in unwarranted classroom behavior. Smart phones give students access to videos, tutorials, quizzes, smart objects, and apps specific to content needs. Smartphones facilitate self-guided learning, when additional resources are needed, to understand or expand on chemistry concepts.

Taken together, these capabilities are creating a world of mobile computing that may have an impact on society, including chemical education that may be even greater than the changes brought about by the personal computer [19]. Careful attention should be given to students presenting difficulty mastering chemistry concepts before assigning supplemental instructions. Differentiation between students, who are weak in one or more subject areas versus students struggling with a concept, should be identified. Chemistry teachers can help students struggling in other subject areas by assigning lessons on Khan Academy to help strengthen weak skills. Students, who struggle with abstract concepts, greatly benefit from online simulations. Laboratory instruction is and should be a central component to every chemistry class. Laboratory instruction allow students to actively learn and engage with their peers. Laboratory prep times, limited supplies, or no access to a laboratory, leaves many chemistry students in secondary schools, shorthanded. Utilizing technology in the classroom, affords the once shorthanded chemistry students, with a virtual chemistry lab. Virtual chemistry, cannot fully replace students skills built during lab but it does give students a realistic idea of how labs work, with the application of newly learned chemistry concepts [26]. Chemistry students, in today's secondary education schools, need instruction that fosters active learning and student-peer engagement, while building $21^{\text {st }}$ century workforce skills. Chemistry instruction, best effective for student learning and building $21^{\text {st }}$ century skills, incorporates social constructivist inquiry, based pedagogies with technology [27]. Chemistry teachers should provide students, who are weak in one or more subject areas, resources to build skills. Material should be presented in a way that is relevant to the student's life [28-32]. It should be critically noted and addressed that during the process of reviewing literature for this research study, published demographics of underrepresented groups in the field of chemistry is the suggestive reason for employment gaps in chemistry and STEM fields [33-37]. Secondary education chemistry teachers must realize that the outcomes of their instructional methods directly impacts the chemistry workforce.

\section{References}

1. Eberlein V, Moog R, Platt T, Varma $P$ (2008) Pedagogies of engagement in science: A Comparison of PBL, POGIL and PLTL. Biochemistry and Molecular Biology Education 36: 262-273

2. Sigel IE, Cocking RR (1977) Cognitive development from childhood to adolescence: A constructivist perspective. In: Holt, Rinehart, Winston. Principles of educational psychology series, New York, London, pp: 1896-1980.

3. Cole RW (2008) Educating Everybody's Children: Diverse Teaching Strategies for Diverse Learners. Revised and Expanded. In: Alexandria VA (ed.), Association for Supervision and Curriculum Development.

4. Barthlow M, Watson S (2014) The Effectiveness of Process-Oriented Guided Inquiry Learning to Reduce Alternative Conceptions in Secondary Chemistry. School Science and Mathematics 114: 5

5. Hendry G, Frommer M, Walker R (1999) Constructivism and Problem-based Learning. Journal of Further and Higher Education 23: 369-371.

6. Vishnumolakala V, Southam D, Treagust D (2017) Students' attitudes, selfefficacy and experiences in a modified process-oriented guided inquiry learning undergraduate chemistry classroom. Chem Educ Res Pract 18: 340-352.

7. Tseng K, Chan C, Lou S, Chen W (2011) Attitudes towards science, technology, engineering and mathematics (STEM) in a project-based learning (PjBL) environment. International Journal of Technology and Design Education 23: 87-102.
8. Tarhan L, Ayar KH, Urek R, Acar B (2008) Problem-Based Learning in 9th Grade Chemistry Class: 'Intermolecular Forces'. Research in Science Education 38 : 285-300.

9. Redish E, Saul J, Steinberg R (1997) On the effectiveness of active-engagement microcomputer-based laboratories. Am J Phys 65: 45.

10. Rhem J (1998) Problem-Based Learning: An Introduction. The National Teaching and Learning Forum 8: 1-7.

11. Oguz A, Arabacioglu S (2011) Overviews on Inquiry-Based and Problem-Based Learning Methods. Western Anatolia Journal of Educational Sciences 307: 303-309.

12. Brown S (2010) A Process-Oriented Guided Inquiry Approach to Teaching Medicinal Chemistry. American Journal of Pharmaceutical Education 74: 121.

13. Hanson DM (2006) Instructor's guide to process-oriented guided-inquiry learning. Stony Brook University.

14. Barron B, Darling HL (2008) Teaching for Meaningful Learning: A Review of Research on Inquiry-Based and Cooperative Learning.

15. Crane E (2015) Project-based learning in the secondary chemistry classroom ProQuest Dissertations and Theses.

16. Ravitz J (2008) Project Based Learning as a Catalyst in Reforming High Schools. New York: Buck Institute for Education.

17. Lai E (2015) 21st Century Skills: One Education Trend Worth Paying Attention to Pearson Research \& Innovation Network. Pearson Research \& Innovation Network.

18. Seery M (2013) Talking Technology. Education in Chemistry.

19. Williams AP (2011) Smart Phones a Powerful Tool in the Chemistry Classroom J Chem Educ 88: 683-686.

20. Khan Academy and the Effectiveness of Science Videos (2011) Action Reaction.

21. Light D, Pierson E (2014) Increasing Student Engagement in Math: The Use of Khan Academy in Chilean Classrooms. International Journal of Education and Development Using Information and Communication Technology 10: 103-119.

22. Squire K, Jenkins H (2011) Video games and learning. New York: Teachers College Press.

23. Dalgarno B, Bishop A, Adlong W, Bedgood D (2009) Effectiveness of a Virtual Laboratory as a preparatory resource for Distance Education chemistry students. Computers \& Education 53: 853-865.

24. Allchin D (2013) Problem and Case-Based Learning in Science: An Introduction to Distinctions, Values, and Outcomes. Cell Biology Education 12: 364-372.

25. Norton S (2006) The use of design practice to teach mathematics and science. International Journal of Technology and Design Education 18: 19-44

26. Potkonjak V, Gardner M, Callaghan V (2016) Virtual laboratories for education in science, technology and engineering: A Review. Computers and Education 95: 309-327.

27. Saavedram AR, Opfer VD (2012) Teaching and Learning $21^{\text {st }}$ Century Skills Lessons from the Learning Sciences. Rand Corporation. Asia Society Partnership for Global Learning. A Global Cities Education Network Report.

28. Davis T, Athey S, Vandevender M (2015) Electrolysis of Water in the Secondary School Science Laboratory with Inexpensive Microfluidics. Journal of Chemical Education 92: 116-119.

29. Prince M (2004) Does Active Learning Work? A Review of the Research Journal of Engineering Education 93: 223-231.

30. Problem-Based Learning CRL (2016).

31. Railsback J (2002) Project-Based Instruction: Creating Excitement for Learning. 32. Rhem J (2015) Editor's Note. The National Teaching \& Learning Forum 25: 3-3. 33. Saba A (2009) Benefits of Technology Integration in Education.

34. Shepherd S, Vogel T (2016) Instruction 2.0: Teaching and/or Incorporating Web 2.0 Technologies in Your Classroom.

35. Strengthen Science Education and the Scientific Workforce (2016) American Chemical Society. 
Citation: Kristen KB, Malinda WG, Monica D, Kendra M (2017) Pedagogical Methods and Technology Used in Chemistry Secondary Education. Mod Chem appl 5: 223. doi: 10.4172/2329-6798.1000223

36. Zawadki R (2010) Is process-oriented guided-inquiry learning (POGIL) suitable as a teaching method in Thailand's higher education. As J Education \& Learning 1: 66-74
37. Tarhan L, Acar B (2007) Problem-based learning in an eleventh-grade chemistry class: 'factors affecting cell potential. Research in Science \& Technological Education 25: 351-369. 